\title{
Authentication of commercially important tuna species landed in Tuticorin coast of Tamil Nadu, India by SE-AFLP method
}

\author{
G. JEYASEKARAN, G. ARUNKUMAR, P. SENTHIL KUMAR, R. JEYA SHAKILA \\ AND D. SUKUMAR \\ Fisheries College and Research Institute, Tamil Nadu Fisheries University, Thoothukudi - 628 008, Tamil Nadu, India \\ e-mail: jeyasekarang@gmail.com
}

\begin{abstract}
Seafood serves as a valuable protein source for human population. Among the seafood, tuna is considered as one of the commercially important species worldwide. Five tuna species namely Euthynnus affinis, Auxis thazard, Katsuwonus pelamis, Thunnus albacares and Thunnus obesus are commonly landed in the Tuticorin coast of Tamil Nadu. Among the five species, the exportable quality and grade of the meat is as follows: T. albacares $>$ T. obesus $>$ K. pelamis $>$ E. affinis $>$ A. thazard. In recent years, mislabeling is done by replacing high value tuna meat with low value tuna meat or with other low value fish meat to earn illegally. Usually, the species identification is done based on the morphological features, but this cannot be applied for the processed fish. PCR based identification methods have gained importance in the identification of fish species. PCR-AFLP is one of the molecular based methods, which can differentiate even closely related species. In this study, SE-AFLP method was employed to differentiate the above five tuna species viz., E. affinis, A. thazard, K. pelamis, T. albacares and T. obesus. Species specific AFLP marker was obtained in the primer combination of EcoR1 for fresh tuna. Band Sharing Index (BSI) analysis was also performed to find the similarities and variation among the five tuna species. AFLP profile of unknown tuna products was compared with the standard AFLP profile and the tuna species authentication was done by analysing BSI score.
\end{abstract}

Keywords: AFLP, Seafood safety, Species authentication, Traceability, Tuna

Fish is an excellent source of protein having good export potential. It is estimated that about 82.4 million $t$ of fish is globally exported every year (FAO, 2013). In India, nearly 9.84 lakh $t$ of seafood products worth 5.0 billion US \$ have been exported in the year 2013-14 (MPEDA, 2015). As the global trade and market for seafood has grown tremendously, the problem of overexploitation and mislabeling of seafood products keep emerging. Mislabeling mainly occurs in the processed fish products like heat processed fish, fish fillets, fish mince and pickles, since the external morphological features are removed during processing.

There are two main analytical methods for the differentiation of fish species, viz., protein and DNA based methods. Most protein based methods like Sodium Dodecyl Sulphate-Polyacrylamide Gel Electrophoresis (SDS-PAGE) and Iso-Electric Focusing (IEF) are found to be effective for fresh fish, but not for processed fishery products, as many proteins get denatured during processing (Teletchea, 2009). Etienne et al. (2000) failed to differentiate species of same genus after cooking, particularly Salmo salar from Salmo trutta and Oncorhynchus gorbuscha from Oncorhynchus keta by SDS-PAGE and Urea IEF techniques.
On the other hand, as DNA is stable in processed condition, molecular method is found to be a reliable identification tool for authentication of seafood species. The usefulness of DNA barcoding in seafood authentication has been described (Nicole et al., 2012). Several molecular based methods like DNA sequencing, species specific Polymerase Chain Reaction (PCR), PCR-Restriction Fragment Length Polymorphism (RFLP), PCR-Amplified Fragment Length Polymorphism (AFLP), multiplex PCR, real time PCR and PCR-Single Strand Conformation Polymorphism (SSCP) have been found successful in differentiating the fish species including the processed products. The potential use of AFLP technology to determine fish and seafood species in processed commercial seafood products and domestic stocks was investigated (Maldini et al., 2006). AFLP technique possesses advantages like requirement of only small amounts of DNA, production of reproducible results, amplification of many restriction fragment subsets by changing the nucleotide extensions on the adaptor sequences, high resolution, applicability to wide variety of DNA samples and no requirement of prior genomic sequence (Vos et al., 1995).

Tuna is an important commercial fish having consumer preference all over the world for its delicacy. Very few 
species of tuna fetch high price due to their larger size and geographical location. Adulteration of processed tuna with less commercially important species in place of high priced tuna is therefore not permissible. In such a situation, it becomes mandatory to devise a suitable molecular authentication technique to monitor the fraudulence practices. A one step triplex-polymerase chain reaction (PCR) based assay was developed to discriminate between three tuna species viz., yellowfin tuna (Thunnus albacares), bigeye tuna (T. obesus) and skipjack tuna (Katsuwonus pelamis) in fresh, frozen and canned forms using mitochondrial cytochrome $b$ gene (Michelini et al., 2007). Identification of four species of tuna viz., bigeye tuna (T. obesus), Pacific bluefin tuna ( $T$. orientalis), southern bluefin tuna (T. maccoyii), and yellowfin tuna (T. albacares) by TaqMan probe based Real Time PCR method was reported (Chuang and Chen, 2012). Application of AFLP assay as a tool to distinguish tuna species for seafood authentication is very much limited. Single enzyme AFLP assay has been used to distinguish the level of genetic variation in three Thunnus species viz., Atlantic northern bluefin tuna (T. thynnus), yellowfin tuna (T. albacares) and albacore (T. alalunga) (Han and Ely, 2002). Zhang et al. (2006) developed AFLP derived SCAR (sequence characterised amplified region) to differentiate Atlantic salmon and rainbow trout. Since the studies on the application of AFLP to authenticate seafood species is very limited, in this study, five major tuna species landed along the coast of Tamil Nadu viz., little tuna (Euthynnus affinis), frigate tuna (Auxis thazard), skipjack tuna (K. pelamis), yellowfin tuna (T. albacares) and bigeye tuna (T. obesus) were examined by Single Enzyme (SE)-AFLP analysis to obtain species specific banding pattern and molecular markers unique for each species.

For the experiment, five tuna species namely A. thazard, E. affinis, K.pelamis, T. albacares and T. obesus were collected from fish landing centres along the coast of Tamil Nadu. They were brought to the laboratory in iced condition and morphologically identified using the FAO fish species identification keys (De Bruin et al., 1995).

Genomic DNA from each species of tuna samples was isolated by using DNA extraction kit (HiPurAMultisample DNA extraction kit, HiMedia laboratories Pvt. Ltd., Mumbai, India) and the integrity of DNA was analysed by running onto $1 \%$ Agarose gel. DNA concentration was quantified by Biophotometer (Eppendorf AG, Germany). Single enzyme-Amplified fragment length polymorphism (SE-AFLP) analysis was performed as described by Han and Ely (2002). About $100 \mathrm{ng}^{-1}$ of DNA was digested with $10 \mathrm{U}$ of $E c o \mathrm{R} 1$ and ligated to adaptor pairs (EcoR1 Forward 5'CTCGTAGACTGCGTACC3' and EcoR1 reverse 5'AATTGG TACGCAGTCTAC3'), in a single reaction tube that contained $1 \mu \mathrm{LNA}\left(100 \mathrm{ng} \mu^{-1}\right), 2 \mu \mathrm{l}$ EcoR1 buffer
(10X), $10 \mathrm{U}$ EcoR1 enzyme, $2 \mu \mathrm{T} 4$ DNA ligase buffer (10X), 5U T4 DNA ligase, 10 pmol of EcoR1 forward and reverse adaptor. This reaction mixture was incubated at $37^{\circ} \mathrm{C}$ for $5 \mathrm{~h}$ and the reaction was then stopped by incubating at $60^{\circ} \mathrm{C}$ for $10 \mathrm{~min}$.

Pre-amplification was done by using EcoR1 specific primers having one selective nucleotide beyond the adaptor sequence EcoR1 5'GACTGCGTACCAATTC[A]3'. The reaction mixture contained $2 \mu \mathrm{l}$ adaptor ligated DNA, 10X PCR buffer [100 mm Tris (pH 9.0), $500 \mathrm{~mm}$ $\mathrm{KCl}, 15 \mathrm{~mm} \mathrm{MgCl}_{2}$ and $0.1 \%$ gelatin], $100 \mathrm{~mm}$ of each dNTPs, $1.25 \mathrm{U}$ of Taq DNA polymerase and $10 \mathrm{pmol}$ of EcoR1 primer having one selective nucleotide, EcoR1 5' GACTGCGTACCAATTC[A]3'. The optimised cycling conditions were initial denaturation at $94^{\circ} \mathrm{C}$ for $1 \mathrm{~min}$, followed by 25 cycles of denaturation at $94^{\circ} \mathrm{C}$ for $1 \mathrm{~min}$, annealing at $56^{\circ} \mathrm{C}$ for $1 \mathrm{~min}$, extension at $72^{\circ} \mathrm{C}$ for $2 \mathrm{~min}$ and final extension of $5 \mathrm{~min}$ at $72^{\circ} \mathrm{C}$. Pre-amplified products were diluted 5 times using molecular grade water.

Selective amplification was done by EcoR1 specific primers having three selective bases beyond the adaptor sequence EcoR1 5'GACTGCGTACCAATTC[NNN]3' as given in Table 1 . The reaction mixture contained $2 \mu \mathrm{l}$ pre-amplified DNA, 10X PCR buffer [100 mm Tris (pH 9.0), $500 \mathrm{~mm} \mathrm{KCl}, 15 \mathrm{~mm} \mathrm{MgCl}_{2}$ and $0.1 \%$ gelatin], $100 \mathrm{~mm}$ of each dNTPs $1.25 \mathrm{U}$ of Taq DNA polymerase and 10 pmol of EcoR1 specific primer, EcoR1 5, GACTGCGTACCAATTC[NNN]3'.The optimised cyclic conditions of the touch-down PCR were: initial denaturation at $94^{\circ} \mathrm{C}$ for $1 \mathrm{~min}$, followed by 10 cycles of denaturation at $94^{\circ} \mathrm{C}$ for $1 \mathrm{~min}$, annealing from $65-56^{\circ} \mathrm{C}$ for 1 min with $1^{\circ} \mathrm{C}$ decrement at each cycle, extension at $72^{\circ} \mathrm{C}$ for $2 \mathrm{~min}$, followed by 35 cycles of denaturation at $94^{\circ} \mathrm{C}$ for $1 \mathrm{~min}$, annealing at $56^{\circ} \mathrm{C}$ for $1 \mathrm{~min}$, extension at $72^{\circ} \mathrm{C}$ for $2 \mathrm{~min}$ and final extension of $10 \mathrm{~min}$ at $72^{\circ} \mathrm{C}$. Amplified products were run on $2 \%$ agarose gel. The size of AFLP fragments was recorded using Gel Documentation System software version 1.2.0.1 (Alpha Innotech, San Leandro, USA).

Table 1. AFLP adaptors and primers used in the study

\begin{tabular}{ll}
\hline Adaptors/Primers & Sequence $\left(5^{\prime}-3^{\prime}\right)$ \\
\hline Adaptors & Sequence $\left(5^{\prime}-3^{\prime}\right)$ \\
$E c o R 1$ forward & CTCGTAGACTGCGTACC \\
Eco 1 reverse & AATTGGTACGCAGTCTAC \\
Pre-amplification primer & GACTGCGTACCAATTCA \\
Selective primers & Sequence $\left(5^{\prime}-3^{\prime}\right)$ \\
E-AGT & GACTGCGTACCAATTCAGT \\
E-AGA & GACTGCGTACCAATTCAGA \\
E-ACG & GACTGCGTACCAATTCACG \\
E-ACT & GACTGCGTACCAATTCACT \\
E-ACC & GACTGCGTACCAATTCACC \\
E-ACA & GACTGCGTACCAATTCACA \\
\hline
\end{tabular}


Binary data matrix was constructed from the AFLP banding pattern obtained using different EcoRl selective primers. The value of ' 1 ' represents the presence of band and ' 0 ' for the absence of band at the specific loci. Band sharing index (BSI) score was then calculated using the following formula:

Band Sharing Index $=\frac{2 \mathrm{~N}_{\mathrm{ab}}}{\mathrm{N}_{\mathrm{a}}+\mathrm{N}_{\mathrm{b}}}$

where, $\mathrm{N}_{\mathrm{ab}}$ - No. of fragments shared between species ' $\mathrm{a}$ ' and ' $\mathrm{b}$ ';

$\mathrm{N}_{\mathrm{a}}$ - Total no. of fragments in species ' $\mathrm{a}$ ', $\mathrm{N}_{\mathrm{b}}$ - Total no. of fragments in species ' $b$ '

PCR-AFLP profiles were generated in this study for the first time for the identification of five tuna species available along the Tamil Nadu coast in India. PCR-AFLP profiles have been recognised as a molecular tool to detect fraud in seafood products (Han and Ely, 2002; Maldini et al., 2006). SE-AFLP analysis was adopted in order to reduce the complexity of the AFLP pattern. Double enzyme-AFLP (DE-AFLP) is mainly used with a combination of restriction enzymes, EcoRI and MseI or TaqI, which provide a highly complex pattern that restricts visualisation in agarose gel and requires a capillary gene sequencer for cluster analysis (Xiang et al., 2010). On the other hand, SE-AFLP analysis employs the use of single enzyme, particularly a rare cutter rather than a frequent cutter. Restriction enzyme, EcoRI with a cutting site at G'AATTC is the most preferred enzyme for SE-AFLP analysis based on its wide availability and lower cost (Han and Ely, 2002). DNA purity is another important aspect to get good quality AFLP fingerprints. The DNA obtained from different species of tuna was high in molecular size ( $>3 \mathrm{~kb}$ ). Vos et al. (1995) also reported that the DNA must be of high molecular size without any shearing.

All the six selective primers viz., E-AGT, E-AGA, E-ACG, E-ACC, E-ACT and E-ACA provided different banding patterns for raw tuna (Fig.1 and 2). The putative loci detected by E-AGT, E-AGA, E-ACC, E-ACT and E-ACA primers ranged between 200 and $1000 \mathrm{bp}$, while those detected by E-ACG primer were from $<50 \mathrm{bp}$ to $250 \mathrm{bp}$. The selective primer E-ACG, could not differentiate the five species of raw tuna due to $90 \%$ similar banding pattern. The primers E-AGA and E-ACT clearly differentiated the five species of raw tuna than E-AGT and E-ACC primers. The primer E-ACA has shown the least differentiation. AFLP profiles distinguish the species based on band sharing index (BSI) (Maldini et al., 2006). About 50\% dissimilarities existed between $K$. pelamis and $A$. thazard; as well as between $T$. albacares and $T$. obesus with E-AGT primer selective amplification. With respect to E-AGA primer, the BSI gave

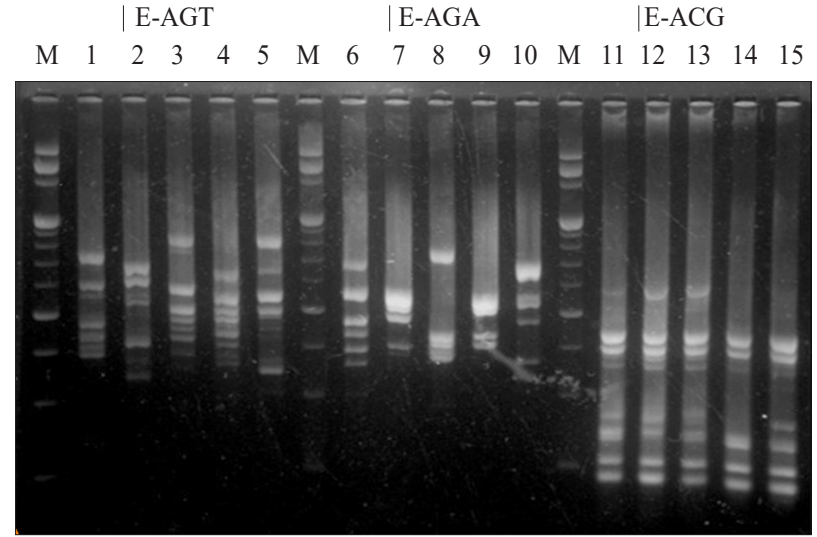

Fig. 1. AFLP profile raw of Tuna species

Lanes 1, 6, 11 - Euthynnus affinis, Lanes 2, 7, 12 - Auxis thazard, Lanes 3, 8, 13 - Katsuwonus pelamis, Lanes 4, 9, 14 - Thunnus albacares, Lanes 5, 10, 15 - Thunnus obesus, Lane M - 100 bp DNA ladder
| E-ACT
E-ACC
| E-ACA

$\begin{array}{llllllllllllllllll}\mathrm{M} & 1 & 2 & 3 & 4 & 5 & \mathrm{M} & 6 & 7 & 8 & 9 & 10 & \mathrm{M} & 11 & 12 & 13 & 14 & 15\end{array}$

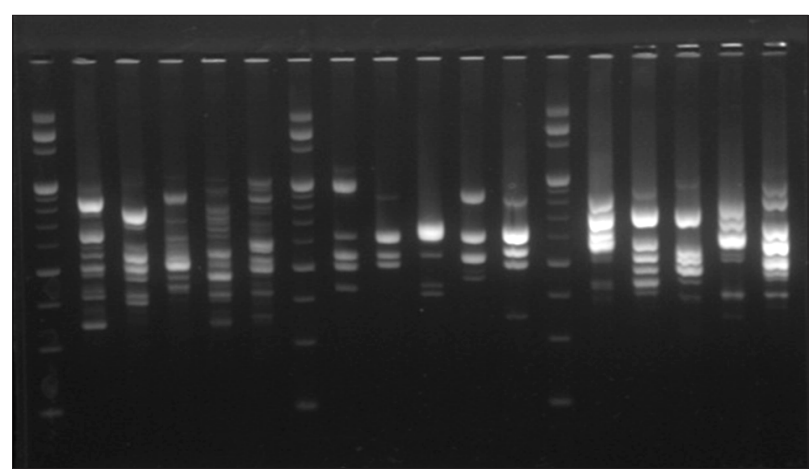

Fig. 2. AFLP profile of raw Tuna species

Lanes 1, 6, 11 - Euthynnus affinis, Lanes 2, 7, 12 - Auxis thazard, Lanes 3, 8, 13 - Katsuwonus pelamis, Lanes 4, 9, 14 - Thunnus albacares, Lanes 5, 10, 15 - Thunnus obesus, Lane M - 100 bp DNA ladder

a different profile with $E$. affinis having $43 \%$ bands different from $T$. obesus. The E-ACG primer was the least effective, as most of the tuna species had only $16-14 \%$ dissimilarities. The primer E-ACC expressed good differentiation among tuna species, except that $A$. thazard had $45 \%$ disparity with T. obesus; and T. albacares had $50 \%$ bands not sharing with T. obesus. The primer E-ACT showed lower differentiation between E. affinis and A. thazard (33\%) and between A. thazard and T. albacares (33\%), but higher disparity between T. albacares and T. obesus (80\%) and hence, proved to be a better selective primer. The E-ACA primer also distinguished the tuna species efficiently with low BSI scores, as T. albacares showed only 13\% dissimilar banding pattern from that of T. obesus (Table 2). 
Table 2. Band sharing index (BSI) of raw tuna species

\begin{tabular}{|c|c|c|c|c|c|}
\hline \multirow{2}{*}{ Species } & \multicolumn{4}{|c|}{ E-AGT } & \multirow[b]{2}{*}{ T. obesus } \\
\hline & E. affinis & A. thazard & K. pelamis & T. albacares & \\
\hline E. affinis & 1 & 0.47 & 0.53 & 0.33 & 0.16 \\
\hline A. thazard & 0.47 & 1 & 0 & 0 & 0.22 \\
\hline K. pelamis & 0.53 & 0 & 1 & 0.37 & 0.18 \\
\hline T. albacares & 0.33 & 0 & 0.37 & 1 & 0.50 \\
\hline T. obesus & 0.16 & 0.22 & 0.18 & 0.50 & 1 \\
\hline \multirow{2}{*}{ Species } & \multicolumn{4}{|c|}{ E-AGA } & \\
\hline & E. affinis & A. thazard & K. pelamis & T. albacares & T. obesus \\
\hline E. affinis & 1 & 0.20 & 0.22 & 0.25 & 0.55 \\
\hline A. thazard & 0.20 & 1 & 0 & 0.33 & 0.22 \\
\hline K. pelamis & 0.22 & 0 & 1 & 0 & 0.25 \\
\hline T. albacares & 0.25 & 0.33 & 0 & 1 & 0.57 \\
\hline T. obesus & 0.55 & 0.22 & 0.25 & 0.57 & 1 \\
\hline \multirow{2}{*}{ Species } & \multicolumn{4}{|c|}{ E-ACG } & \\
\hline & E. affinis & A. thazard & K. pelamis & T. albacares & T. obesus \\
\hline E. affinis & 1 & 0.94 & 0.94 & 0.86 & 0.93 \\
\hline A. thazard & 0.94 & 1 & 1 & 0.80 & 0.875 \\
\hline K. pelamis & 0.94 & 1 & 1 & 0.80 & 0.875 \\
\hline T. albacares & 0.86 & 0.80 & 0.80 & 1 & 0.92 \\
\hline T. obesus & 0.93 & 0.875 & 0.875 & 0.92 & 1 \\
\hline \multirow{2}{*}{ Species } & \multicolumn{4}{|c|}{ E-ACC } & \\
\hline & E. affinis & A. thazard & K. pelamis & T. albacares & T. obesus \\
\hline E. affinis & 1 & 0.38 & 0.11 & 0.37 & 0.32 \\
\hline A. thazard & 0.38 & 1 & 0 & 0.33 & 0.55 \\
\hline K. pelamis & 0.11 & 0 & 1 & 0.29 & 0.11 \\
\hline T. albacares & 0.37 & 0.33 & 0.29 & 1 & 0.50 \\
\hline T. obesus & 0.32 & 0.55 & 0.11 & 0.50 & 1 \\
\hline \multirow{2}{*}{ Species } & \multicolumn{4}{|c|}{ E-ACT } & \\
\hline & E. affinis & A. thazard & K. pelamis & T. albacares & T. obesus \\
\hline E. affinis & 1 & 0.67 & 0.44 & 0.40 & 0.40 \\
\hline A. thazard & 0.67 & 1 & 0.50 & 0.67 & 0.44 \\
\hline K. pelamis & 0.44 & 0.50 & 1 & 0.44 & 0.22 \\
\hline T. albacares & 0.40 & 0.67 & 0.44 & 1 & 0.20 \\
\hline T. obesus & 0.40 & 0.44 & 0.22 & 0.20 & 1 \\
\hline \multirow{2}{*}{ Species } & \multicolumn{4}{|c|}{ E-ACA } & \\
\hline & E. affinis & A. thazard & K. pelamis & T. albacares & T. obesus \\
\hline E. affinis & 1 & 0.31 & 0.17 & 0.33 & 0.27 \\
\hline A. thazard & 0.31 & 1 & 0.46 & 0.15 & 0.38 \\
\hline K. pelamis & 0.17 & 0.46 & 1 & 0.17 & 0.27 \\
\hline T. albacares & 0.33 & 0.15 & 0.17 & 1 & 0.13 \\
\hline T. obesus & 0.27 & 0.38 & 0.27 & 0.13 & 1 \\
\hline
\end{tabular}

AFLP appears to provide extremely informative markers for species identification and authenticity testing of unknown fish species (Yu and Guo, 2004). AFLP marker regions were identified in few tuna species from the AFLP profiles of different raw tuna species (Table 3). AFLP markers were identified with most of the selective primers, except E-ACG. It was found that primers E-ACT and E-ACA alone can differentiate $T$. albacares and $T$. obesus with different 
Table 3. AFLP markers of raw tuna species

\begin{tabular}{|c|c|c|c|c|c|}
\hline \multirow{2}{*}{ Primers } & \multicolumn{5}{|c|}{ AFLP makers (bp) } \\
\hline & E. affinis & A. thazard & K. pelamis & T. albacares & T. obesus \\
\hline E-AGT & 740 & 675 & 575 & - & 350 \\
\hline E-AGA & 450,370 & 480 & 750 & - & - \\
\hline E-ACG & - & - & - & - & - \\
\hline E-ACC & 850,350 & 700 & - & - & 1020 \\
\hline E-ACT & 1000 & - & 400 & 450 & 350 \\
\hline E-ACA & - & 410 & - & 730 & 800 \\
\hline
\end{tabular}

selective markers. The primers E-AGT and E-ACC can also distinguish these two species and each had one AFLP marker specific for T. obesus at 350 and 1020 bp respectively. AFLP markers for other small tuna species were also identified using E-AGT and E-AGA primers.

Species specific AFLP marker can be obtained for the products of little known genetic background due to high reproducibility of AFLP, based on the restriction endonuclease digestion and flexibility in the design of primer combinations (Liu and Cordes, 2004). Han and Ely (2002) developed a modified AFLP method using only one restriction enzyme, EcoR1, for obtaining species specific patterns for Morone and Thunnus species, but have not identified any species specific AFLP markers. This was the only report available on the AFLP profiling of tuna species. In the present study, AFLP species specific patterns were additionally obtained for another three species of tuna, in addition to Thunnus spp. viz., T. albacares and T. obesus

All the selective primers examined in this study, except E-ACG, were efficient in distinguishing the raw tuna species. Clear authentication of $T$. albacares and T. obesus were achieved using E-ACA and E-ACT primers. Hence, the identified AFLP marker region could be further purified and sequenced to develop selective PCR methodologies for selective identification of processed tuna products after validation.

\section{Acknowledgements}

Authors gratefully acknowledge the Science and Engineering Research Board, Ministry of Food Processing Industries (SERB-MFPI), Govt. of India, New Delhi, India for the financial assistance extended to this project. The authors thank the Vice-Chancellor, Tamil Nadu Fisheries University, Nagapattinam for his encouragement in carrying out this research work.

\section{References}

Chuang, P. S., Chen, M. I. and Shiao, J. C. 2012. Identification of tuna species by a real-time polymerase chain reaction technique. Food Chem., 133: 1055-1061.
De Bruin, G. H. P., Russell, B. C. and Bogusch, A. 1995. FAO species identification field guide for fishery purposes. The marine fishery resources of Sri Lanka, Food and Agriculture Organization of the United Nations, Rome, Italy, p. 316-320.

Etienne, M., Jerome, M. and Fleurence, J. 2000. Identification of fish species after cooking by SDS-PAGE and urea IEF: a collaborative study. J. Agri. Food Chem., 48: 2653-2658.

FAO 2013. Global capture fisheries production statistics for the year 2011. Fisheries and Aquaculture Department.Food and Agriculture Organization of the United Nations.www.fao.org/ fishery/capture/en. (Accessed 20 July 2015)

Han, K. and Ely. B. 2002. Use of AFLP analyses to assess genetic variation in Morone and Thunnus species. Mar. Biotechnol., 4: $141-145$.

Liu, Z. J. and Cordes, J. F. 2004. DNA marker technologies and their applications in aquaculture genetics. Aquaculture, 238: 31-37.

Maldini, M., Marzano, F. N., Fortes, G. G., Papa, R. and Gandolfi, G. 2006. Fish and seafood traceability based on AFLP markers: Elaboration of a species database. Aquaculture, 261: 487-494.

Michelini, E., Cevenini, L., Mezzanotte, L., Simoni, P., Baraldini, M., Laude, L. D. and Roda, A. 2007. One-step triplexpolymerase chain reaction assay for the authentication of yellowfin (Thunnus albacares), bigeye (Thunnus obesus) and skipjack (Katsuwonus pelamis) tuna DNA from fresh, frozen and canned tuna samples. J. Agri. Food Chem., 55: 7638-7647.

MPEDA 2015. Marine Products Export Development Authority. http://www.mpeda.com/ (Accessed 30 April 2015).

Nicole, S., Negrisolo, E., Eacher, G., Mantovani, R., Patarnello, T., Erickson, D. L., Kress, W. J. and Barcaccia, G. 2012. DNA barcoding as a reliable method for the authentication of commercial seafood products. Food Technol. Biotechnol., 50(4): 387-398.

Teletchea, F. 2009. Molecular identification methods of fish species: reassessment and possible applications. Rev. Fish Biol. Fish., 19: 265-293.

Vos, P., Hogers, R., Bleeker, M., Reijans, M., Van de Lee, T. and Hornes, M. 1995. AFLP: a new technique for DNA fingerprinting. Nucleic Acids Res., 23: 4407-4414. 
Xiang, S. R., Cook, M., Saucier, S., Gillispie, P., Socha, R., Scroggins, R. and Beaudette, L. A. 2010. Development of Amplified Fragment Length Polymorphism - derived functional strain-specific markers to assess the persistence of 10 bacterial strains in soil microcosms. Appl. Environ. Microbiol., 76: 7126-7135.
Yu, Z. and Guo, X. 2004. Genetic analysis of selected strains of eastern oyster (Crassostrea virginica) using AFLP and microsatellite markers. Mar. Biotechnol., 6: 575-586.

Zhang, J., Wang, H. and Cai, Z. 2006. The application of DGGE and AFLP- derived SCAR for discrimination between Atlantic salmon (Salmo salar) and rainbow trout (Oncorhynchus mykiss). Food Control, 18(6): 672-676. 